\title{
REVIEW
}

\section{Extracorporeal carbon dioxide removal for patients with acute respiratory failure secondary to the acute respiratory distress syndrome: a systematic review}

Marianne Fitzgerald*, Jonathan Millar, Bronagh Blackwood, Andrew Davies, Stephen J Brett, Daniel F McAuley and James J McNamee

\begin{abstract}
Acute respiratory distress syndrome (ARDS) continues to have significant mortality and morbidity. The only intervention proven to reduce mortality is the use of lung-protective mechanical ventilation strategies, although such a strategy may lead to problematic hypercapnia. Extracorporeal carbon dioxide removal $\left(\mathrm{ECCO}_{2} \mathrm{R}\right)$ devices allow uncoupling of ventilation from oxygenation, thereby removing carbon dioxide and facilitating lower tidal volume ventilation. We performed a systematic review to assess efficacy, complication rates, and utility of $\mathrm{ECCO}_{2} \mathrm{R}$ devices. We included randomised controlled trials (RCTs), case-control studies and case series with 10 or more patients. We searched MEDLINE, Embase, LILACS (Literatura Latino Americana em Ciências da Saúde), and ISI Web of Science, in addition to grey literature and clinical trials registries. Data were independently extracted by two reviewers against predefined criteria and agreement was reached by consensus. Outcomes of interest included mortality, intensive care and hospital lengths of stay, respiratory parameters and complications. The review included 14 studies with 495 patients (two RCTs and 12 observational studies). Arteriovenous $\mathrm{ECCO}_{2} \mathrm{R}$ was used in seven studies, and venovenous $\mathrm{ECCO}_{2} \mathrm{R}$ in seven studies. Available evidence suggests no mortality benefit to $\mathrm{ECCO}_{2} \mathrm{R}$, although post hoc analysis of data from the most recent $\mathrm{RCT}$ showed an improvement in ventilator-free days in more severe ARDS. Organ failure-free days or ICU stay have not been shown to decrease with $\mathrm{ECCO}_{2} \mathrm{R}$. Carbon dioxide removal was widely demonstrated as feasible, facilitating the use of lower tidal volume ventilation. Complication rates varied greatly across the included studies, representing technological advances. There was a general paucity of high-quality data and significant variation in both practice and technology used among studies, which confounded analysis. $\mathrm{ECCO}_{2} \mathrm{R}$ is a rapidly evolving technology and is an efficacious treatment to enable protective lung ventilation. Evidence for a positive effect on mortality and other important clinical outcomes is lacking. Rapid technological advances have led to major changes in these devices and together with variation in study design have limited applicability of analysis. Further well-designed adequately powered RCTs are needed.
\end{abstract}

\footnotetext{
* Correspondence: mfitzgerald09@qub.ac.uk

Centre for Infection and Immunity, School of Medicine, Dentistry and

Biomedical Science, Queen's University Belfast, 97 Lisburn Road, Belfast BT9

$7 A E, U K$
}



C 2014 Fitzgerald et al.; licensee BioMed Central Ltd. The licensee has exclusive rights to distribute this article, in any medium, for 12 months following its publication. After this time, the article is available under the terms of the Creative Commons Attribution License (http://creativecommons.org/licenses/by/2.0), which permits unrestricted use, distribution, and reproduction in any medium, provided the original work is properly cited. 


\section{Introduction}

Acute respiratory distress syndrome (ARDS) is associated with significant mortality and morbidity [1]. Tidal recruitment, alveolar derecruitment and high inspiratory volumes during mechanical ventilation add further insult to already injured and failing lungs [2]. Few interventions have been proven to reduce mortality, with the notable exception of low tidal volume ventilation [3]. In practice, lung-protective strategies involving low tidal volume ventilation can prove difficult to implement, often due to concerns of hypercapnia or its potential adverse physiological consequences [4].

Extracorporeal carbon dioxide removal $\left(\mathrm{ECCO}_{2} \mathrm{R}\right)$ offers a potentially attractive solution to this problem because carbon dioxide can be 'dialysed' out of the blood, while the lungs are ventilated in a maximally protective manner [5]. Techniques to achieve this have existed since the late 1970s [6,7], but widespread uptake has been limited due to the paucity of trial data, the demanding technical requirements of the technique and concerns regarding complications [8]. More recently, modern developments in $\mathrm{ECCO}_{2} \mathrm{R}$ technology have stimulated renewed interest [9], particularly because of the potential for safe use in nonspecialist centres. To define current understanding of $\mathrm{ECCO}_{2} \mathrm{R}$ in patients with acute respiratory failure and inform future randomised controlled trials (RCTs), we performed a systematic review to assess efficacy and complication rates of $\mathrm{ECCO}_{2} \mathrm{R}$.

\section{Review}

Design

The systematic review protocol was published in the PROSPERO database [10] and complies with Preferred Reporting Items for Systematic reviews and MetaAnalysis guidelines [11].

We searched the MEDLINE, Embase, LILACS (Literatura Latino Americana em Ciências da Saúde) and ISI Web of Science databases (1976 to January 2014) using a strategy developed by a trained medical librarian, combining medical subject headings and keywords such as interventional lung assist, extracorporeal and ARDS (see Additional file 1 for the full MEDLINE search strategy). Citations were screened by title/abstract level, and if they were potentially relevant the full text was retrieved and reviewed by MF and JM. We also reviewed reference lists of identified studies and relevant review papers.

The search of grey literature included Opengray, NHS Evidence, National Institute of Clinical Evidence and the Scottish Intercollegiate Guidelines Network. To identify planned or current studies we examined major clinical trial registries [12-14]. Novalung GmbH (Talheim, Germany), who manufacture the interventional lung assist and iLA Activve $^{\oplus}$, were consulted to identify any current studies. The search strategy included no language restriction.
Inclusion criteria were: type of study - RCT or observational (for example, case-control or case series) including 10 or more patients; type of participants - adult patients ( $>18$ years) with ARDS (or acute respiratory failure in studies occurring prior to the American-European Consensus Conference Committee definition of ARDS in 1994); type of interventions - arteriovenous or venovenous $\mathrm{ECCO}_{2} \mathrm{R}$ device; and type of outcomes - hospital or ICU mortality, hospital or ICU length of stay, ventilatorfree days (VFDs), organ failure-free days, quantified carbon dioxide removal, and reported complications.

\section{Study selection}

Two authors (MF and JM) independently reviewed the retrieved abstracts and assessed eligibility. Full-text articles were retrieved and assessed to confirm eligibility. Disagreement was resolved by consensus with a third author (DFM).

\section{Data extraction}

Data from included studies were independently extracted by MF and JM, using a pre-piloted data extraction form (Additional file 2). Disagreements were resolved by a third author (BB). We extracted the following data: study design, study and participant characteristics, study intervention and setting, relevant outcome data, and complications.

\section{Assessment of methodological quality}

Two authors (MF and JM) independently assessed methodological quality. Observational studies were assessed using the Critical Appraisal Skills Programme tools and, for case series, a specific checklist $[15,16]$. RCTs were assessed using the risk of bias domain-based evaluation as described in the Cochrane Handbook for Systematic Reviews of Interventions [17].

\section{Search results}

The search identified 147 citations from database searches and reference lists (Figure 1). Following removal of duplicates $(n=9)$, removal of those not meeting screening eligibility criteria $(n=118)$ and full-text exclusions ( $n=6$; see Additional file 3 ), 14 studies were included in this review (two RCTs and 12 observational studies) [18-31].

A search of the grey literature revealed two abstracts presented at an international conference [32,33]. The first was for a retrospective analysis of 325 patients with ARDS and acute kidney injury treated with continuous renal replacement therapy with or without $\mathrm{ECCO}_{2} \mathrm{R}$ [32]. The second abstract described a study of 10 patients using percutaneous extracorporeal lung assist combined with continuous renal replacement therapy [33]. 


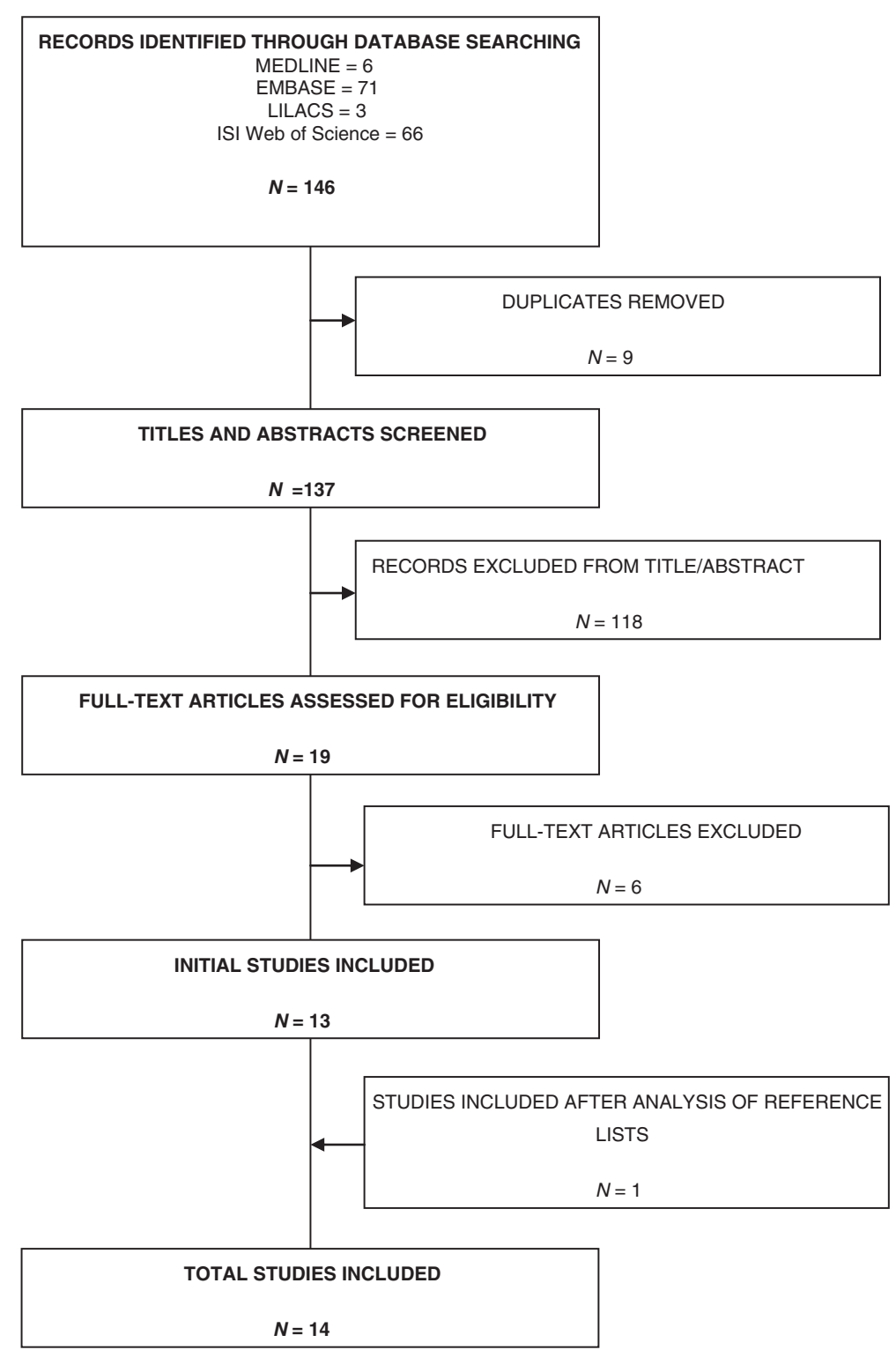

Figure 1 Literature search. LILACS, Literatura Latino Americana em Ciências da Saúde.

Limited information was provided in both cases, and so neither abstract was included in our analysis.

One health technology assessment of an arteriovenous $\mathrm{ECCO}_{2} \mathrm{R}$ device was identified [34].

\section{Characteristics of included studies}

In total, 14 studies were included: two RCTs (Table 1) $[18,19]$, and six prospective observational studies [20-25] and six retrospective studies [26-31] (Table 2). The earliest study dated from 1986 and the most recent from 2013. Among included studies, nine were from Germany, two were from France, two were from Italy, and one was from the United States. All of the studies were published in peer-reviewed journals. Only one study was multicentre in design [19]. The population studied was defined as ARDS in 13 studies and acute respiratory failure in one study [24].

The configuration of $\mathrm{ECCO}_{2} \mathrm{R}$ differed across studies, with seven using arteriovenous circuits and seven using venovenous circuits. Only one study conducted after 2000 examined the use of a venovenous device [21]. In total this systematic review included analysis of 335 patient cases of arteriovenous $\mathrm{ECCO}_{2} \mathrm{R}$ and 160 cases of venovenous $\mathrm{ECCO}_{2} \mathrm{R}$.

\section{Risk of bias in included studies}

Given the nature of the intervention, neither RCT was blinded to allocation. Both RCTs reported an intention- 
Table 1 Description of included randomised controlled trials

\begin{tabular}{|c|c|c|c|c|c|c|c|c|c|c|c|c|c|c|}
\hline \multirow[t]{2}{*}{ Study } & \multirow[t]{2}{*}{ Year } & \multirow[t]{2}{*}{$N$} & \multirow[t]{2}{*}{ Intervention } & \multirow[t]{2}{*}{ Control } & \multirow{2}{*}{$\begin{array}{l}\text { Mean } \\
\text { age }^{a}\end{array}$} & \multirow{2}{*}{$\begin{array}{l}\text { Male/ } \\
\text { female }^{a}\end{array}$} & \multirow{2}{*}{$\begin{array}{l}\text { Primary } \\
\text { outcome } \\
\text { measure }\end{array}$} & \multirow[t]{2}{*}{ Secondary outcome measures } & \multicolumn{3}{|l|}{$\mathrm{VFD}^{\mathbf{b}}$} & \multicolumn{3}{|c|}{ Mortality $^{c}$} \\
\hline & & & & & & & & & $\mathrm{I}$ & $\mathrm{C}$ & $\begin{array}{l}P \\
\text { value }\end{array}$ & $\mathrm{I}$ & $\mathrm{C}$ & $\begin{array}{l}P \\
\text { value }\end{array}$ \\
\hline $\begin{array}{l}\text { Bein and } \\
\text { colleagues } \\
{[19]}\end{array}$ & 2013 & 79 & iLA & $\begin{array}{l}\text { ARDSnet } \\
\text { ventilation }\end{array}$ & $\begin{array}{l}49.8 \pm \\
12 \\
(48.7 \\
\pm 17)\end{array}$ & $\begin{array}{l}38 / 2 \\
(30 / 9)\end{array}$ & $\begin{array}{l}\text { Ventilator- } \\
\text { free days } \\
\text { ( } 28 \text { and } \\
60 \text { days) }\end{array}$ & $\begin{array}{l}\text { Respiratory parameters, haemodynamics, inflammatory } \\
\text { response, transfusion requirements, analgesic/sedative } \\
\text { requirements, catecholamine requirements, frequency and } \\
\text { duration of RRT, organ failure-free days, frequency and duration } \\
\text { of adjunctive therapies, complications, ICU and hospital LOS, } \\
\text { in-hospital mortality }\end{array}$ & $\begin{array}{l}10 \pm \\
8 \\
(33.2 \\
\pm 20)\end{array}$ & $\begin{array}{l}9.3 \pm \\
9 \\
(29.2 \\
\pm 21)\end{array}$ & $\begin{array}{l}0.779 \\
(0.469)\end{array}$ & $\begin{array}{l}7 / 40 \\
(17.5 \%)\end{array}$ & $\begin{array}{l}6 / 39 \\
(15.4 \%)\end{array}$ & 0.000 \\
\hline $\begin{array}{l}\text { Morris and } \\
\text { colleagues } \\
{[18]}\end{array}$ & 1994 & 40 & $\begin{array}{l}\text { PCIRV then } \\
\text { LFPPV + W } \\
\mathrm{ECCO}_{2} \mathrm{R}\end{array}$ & $\begin{array}{l}\text { Standardised } \\
\text { CPPV }\end{array}$ & $\begin{array}{l}33 \pm \\
3.1 \\
(35 \pm \\
2.3)\end{array}$ & $\begin{array}{l}8 / 13 \\
(9 / 10)\end{array}$ & $\begin{array}{l}\text { 30-day } \\
\text { mortality }\end{array}$ & $\begin{array}{l}\text { Respiratory parameters, transfusion requirements, complications, } \\
\text { ICU and hospital LOS, economic analysis }\end{array}$ & $N R$ & & & $\begin{array}{l}14 / 21 \\
(66.6 \%)\end{array}$ & $\begin{array}{l}11 / 19 \\
(57.9 \%)\end{array}$ & 0.56 \\
\hline
\end{tabular}

C, control group; CPPV, conventional positive pressure ventilation; I, intervention group; iLA, interventional lung assist; LFPPV, low-frequency positive-pressure ventilation; LOS, length of stay; NR, not recorded; PCIRV, pressure controlled inverse ratio ventilation; $\mathrm{RRT}$, renal replacement therapy; $\mathrm{WVECCO} 2 \mathrm{R}$, venovenous extracorporeal carbon dioxide removal. ${ }^{\mathrm{a}}$ Intervention (control). ${ }^{\mathrm{b}} \mathrm{Ventilator-free}$ days at 28 days (60 days). In-hospital mortality for Bein and colleagues [19], and 30-day mortality for Morris and colleagues [18]. 
Table 2 Description of included nonrandomised studies

\begin{tabular}{|c|c|c|c|c|c|c|c|c|c|}
\hline Study & Design & Year & $N$ & Intervention & $\begin{array}{l}\text { Mean } \\
\text { age } \\
\text { (years) }\end{array}$ & $\begin{array}{l}\text { Male/ } \\
\text { female }\end{array}$ & Outcomes measured & $\begin{array}{l}\text { Mortality } \\
\text { (\%) }\end{array}$ & Grade \\
\hline $\begin{array}{l}\text { Forster and } \\
\text { colleagues [25] }\end{array}$ & $\begin{array}{l}\text { Prospective } \\
\text { case series }\end{array}$ & 2013 & 10 & $\begin{array}{l}\text { W (with } \\
\text { CRRT) }\end{array}$ & 60 & $7 / 3$ & $\begin{array}{l}\text { Respiratory and haemodynamic } \\
\text { parameters, complications, mortality }\end{array}$ & 40 & 3 \\
\hline $\begin{array}{l}\text { Nierhaus and } \\
\text { colleagues [29] }\end{array}$ & $\begin{array}{l}\text { Retrospective } \\
\text { case series }\end{array}$ & 2011 & 13 & $A V$ & 52 & $8 / 5$ & $\begin{array}{l}\text { Respiratory parameters, ICU LOS, } \\
\text { complications, mortality }\end{array}$ & 54 & 3 \\
\hline $\begin{array}{l}\text { Weber-Carstens } \\
\text { and colleagues [26] }\end{array}$ & $\begin{array}{l}\text { Retrospective } \\
\text { case series }\end{array}$ & 2009 & 10 & $A V$ & 54 & $6 / 4$ & $\begin{array}{l}\text { Respiratory parameters, sedation scores, } \\
\text { ICU LOS, mortality }\end{array}$ & 60 & 3 \\
\hline $\begin{array}{l}\text { Zimmermann and } \\
\text { colleagues [20] }\end{array}$ & $\begin{array}{l}\text { Prospective } \\
\text { case series }\end{array}$ & 2009 & 51 & $A V$ & 52 & $43 / 8$ & $\begin{array}{l}\text { Respiratory parameters, haemodynamics, } \\
\text { complications, mortality }\end{array}$ & 49 & 3 \\
\hline $\begin{array}{l}\text { Terragni and } \\
\text { colleagues [21] }\end{array}$ & $\begin{array}{l}\text { Prospective } \\
\text { cross-sectional } \\
\text { study }\end{array}$ & 2009 & 32 & W & 66 & $22 / 10$ & $\begin{array}{l}\text { Respiratory parameters, lung morphology, } \\
\text { inflammatory response, complications }\end{array}$ & NR & $2+$ \\
\hline $\begin{array}{l}\text { Muellenbach and } \\
\text { colleagues [27] }\end{array}$ & $\begin{array}{l}\text { Retrospective } \\
\text { case series }\end{array}$ & 2008 & 22 & $A V$ & 38 & $20 / 2$ & $\begin{array}{l}\text { Respiratory parameters, haemodynamics, } \\
\text { complications, ventilator-free days, ICU } \\
\text { LOS, mortality }\end{array}$ & 27 & 3 \\
\hline $\begin{array}{l}\text { Bein and } \\
\text { colleagues [28] }\end{array}$ & $\begin{array}{l}\text { Retrospective } \\
\text { case series }\end{array}$ & 2006 & 90 & $A V$ & 44 & $69 / 21$ & $\begin{array}{l}\text { Respiratory parameters, haemodynamics, } \\
\text { complications, mortality }\end{array}$ & 59 & 3 \\
\hline $\begin{array}{l}\text { Liebold and } \\
\text { colleagues [30] }\end{array}$ & $\begin{array}{l}\text { Retrospective } \\
\text { case series }\end{array}$ & 2002 & 70 & $A V$ & 41 & $55 / 15$ & $\begin{array}{l}\text { Respiratory parameters, complications, } \\
\text { mortality }\end{array}$ & 64 & 3 \\
\hline $\begin{array}{l}\text { Guinard and } \\
\text { colleagues [22] }\end{array}$ & $\begin{array}{l}\text { Prospective } \\
\text { cross-sectional } \\
\text { study }\end{array}$ & 1997 & 10 & W & NR & NR & $\begin{array}{l}\text { Respiratory parameters, complications, } \\
\text { mortality }\end{array}$ & 75 & $2+$ \\
\hline $\begin{array}{l}\text { Brunet and } \\
\text { colleagues [23] }\end{array}$ & $\begin{array}{l}\text { Prospective } \\
\text { case series }\end{array}$ & 1994 & 11 & W & 27 & $4 / 7$ & Respiratory parameters, mortality & 27 & 3 \\
\hline $\begin{array}{l}\text { Bindslev and } \\
\text { colleagues [31] }\end{array}$ & $\begin{array}{l}\text { Retrospective } \\
\text { case series }\end{array}$ & 1991 & 14 & W & 31 & $11 / 3$ & $\begin{array}{l}\text { Respiratory parameters, complications, } \\
\text { mortality }\end{array}$ & 57 & 3 \\
\hline $\begin{array}{l}\text { Gattinoni and } \\
\text { colleagues [24] }\end{array}$ & $\begin{array}{l}\text { Prospective } \\
\text { case series }\end{array}$ & 1986 & 43 & W & 26 & $18 / 25$ & $\begin{array}{l}\text { Respiratory parameters, haemodynamics, } \\
\text { complications, mortality }\end{array}$ & 51 & 3 \\
\hline Total & & & 376 & & & $\begin{array}{l}263 / 103 \\
(+10 N R)\end{array}$ & & & \\
\hline
\end{tabular}

$\mathrm{AV}$, arteriovenous; CRRT, continuous renal replacement therapy; LOS, length of stay; NR, not recorded; VV, venovenous.

to-treat analysis. Both trials scored a low risk of bias on all domains, except in Morris and colleagues' paper where the sequence generation was unclear [18] (Table 3). Both RCT studies halted recruitment earlier than planned, as in both cases interim analysis concluded that the difference between new and control therapies was too small for a significant survival improvement to be demonstrated.

The Xtravent study by Bein and colleagues presented an overall low risk of bias [19] (Table 3). Although the initial sample size calculation conducted by the Xtravent trialists suggested that 120 patients (53 patients per group for a power of 0.8 and an alpha of 0.05 ) would need to be recruited to identify a significant increase in 28-day VFDs (the primary outcome measure), following a planned interim analysis after enrolment of 56 patients the study period was limited to 3 years because a significant difference was not likely to be shown in the planned cohort. At conclusion, the study had enrolled 79 patients.

The study by Morris and colleagues was judged to present a low risk of bias [18] (Table 3). The study aimed to recruit 60 patients, but was halted after 40 participants were enrolled. This occurred after a predefined interim analysis concluded that the survival difference between the intervention and control therapies was too small for a significant difference to be demonstrated with 60 randomised patients. Analysis after 40 patients found a small difference in survival between the control group and the $\mathrm{ECCO}_{2} \mathrm{R}$ group (mean survival, $30 \%$ in $\mathrm{ECCO}_{2} \mathrm{R}$ patients versus $39 \%$ in controls), and it

Table 3 Risk of bias and methodological quality assessment of included randomised controlled trials

\begin{tabular}{|c|c|c|c|c|c|}
\hline Study & Sequence generation & Allocation concealment & Selective outcome reporting & Other bias & Summary \\
\hline Bein and colleagues [19] & Low & Low & Low & Low $^{a}$ & Low \\
\hline Morris and colleagues [18] & Unclear & Low & Low & Low $^{\mathrm{b}}$ & Low \\
\hline
\end{tabular}

${ }^{\mathrm{a}}$ Trial stopped early due to futility. ${ }^{\mathrm{b}}$ Trial stopped early after an interim analysis showed treatment effect too small to be demonstrated by proposed sample size. 
was projected that 400 patients would be needed to demonstrate statistical significance.

\section{Effect of interventions}

Given the variation in study designs a meta-analysis was considered to be inappropriate and data were descriptively synthesised.

\section{Primary outcome}

Mortality was the primary outcome. Thirteen studies presented data on mortality [18-20,22-31]. Neither RCT demonstrated a statistically significant difference in hospital mortality for those undergoing $\mathrm{ECCO}_{2} \mathrm{R}$. Interestingly, the latest RCT reported a relatively low mortality (control group, 15\%; $\mathrm{ECCO}_{2} \mathrm{R}$ group, $18 \%$ ), which is in keeping with mortality figures from other recent ARDS studies [35], suggesting that overall survival from ARDS is improving. The observational studies reported mortality rates ranging from 27 to $75 \%$ (mean 55.5\%, standard deviation 47.2 to 60.3 ).

\section{Secondary outcomes Ventilator-free days}

Two studies reported VFDs [18,27]. The primary outcome measure in the Xtravent study was VFDs to 28 and 60 days [19]. Subgroup analysis of those patients with partial pressure of arterial oxygen $\left(\mathrm{PaO}_{2}\right) /$ fraction of inspired oxygen $\left(\mathrm{FiO}_{2}\right)<150$ demonstrated a significant increase in VFDs in those receiving $\mathrm{ECCO}_{2} \mathrm{R}$ at both 28 and 60 days (mean \pm standard deviation $11.3 \pm$ 7.5 versus $5 \pm 6.3$ days, $P=0.033$ and $40.9 \pm 12.8$ versus $28.2 \pm 16.4$ days, $P=0.033$, respectively). This increase in VFDs was not seen in patients with higher $\mathrm{PaO}_{2} / \mathrm{FiO}_{2}$ ratios.

\section{Duration of ICU stay and organ failure-free days}

Five studies (two RCTs and three retrospective studies) reported ICU length of stay $[18,19,26,27,29]$. Neither RCT demonstrated a significant reduction in ICU length of stay. Both RCTs also reported hospital length of stay, but did not demonstrate a difference between groups.

Only the Xtravent study reported on organ failure-free days, and demonstrated no difference between groups [19].

Respiratory parameters including carbon dioxide removal Significant variation existed in the respiratory parameters measured among studies (Table 4). Several studies reported comparative analysis of respiratory parameters between survivors and nonsurvivors of $\mathrm{ECCO}_{2} \mathrm{R}$ $[24,27,28]$, whilst other studies reported measurements at varying time points, from 2 hours after initiation of $\mathrm{ECCO}_{2} \mathrm{R}$ to its discontinuation.

The Xtravent study demonstrated a significant reduction in tidal volume, minute ventilation and $\Delta \mathrm{P}$ (plateau pressure - positive end-expiratory pressure) in the $\mathrm{ECCO}_{2} \mathrm{R}$ group, which was sustained across several days of therapy [19]. Morris and colleagues also reported a sustained reduction in tidal volume in those undergoing $\mathrm{ECCO}_{2} \mathrm{R}$, with an initial improvement in peak inspiratory pressures [18]. In both RCTs, tidal volumes approaching $3 \mathrm{ml} / \mathrm{kg}$ predicted body weight were achieved at least in the initial period after initiation of $\mathrm{ECCO}_{2} \mathrm{R}$.

Nonrandomised studies reported outcomes at varying times after commencing $\mathrm{ECCO}_{2} \mathrm{R}$ ranging from 2 hours [28] to decannulation [29]. In the early period (to day 1 ), all showed reductions in tidal volume, peak inspiratory pressure, arterial partial pressure of carbon dioxide and increase in arterial $\mathrm{pH}$. The level of positive endexpiratory pressure administered to patients remained largely unchanged in the majority of studies. The $\mathrm{PaO}_{2} /$ $\mathrm{FiO}_{2}$ ratio increased in all but three studies [19,24,25]. Carbon dioxide removal was quantitatively possible using strategies of arteriovenous carbon dioxide removal $[19,21,26,29]$ (Table 4).

\section{Complications}

All but one study [22] reported on complications encountered with $\mathrm{ECCO}_{2} \mathrm{R}$ therapy (Table 5). Complication rates ranged from 0 to $25 \%$. Five studies reported rates in excess of 20\% [21,27-30]. Amongst studies examining arteriovenous devices, the most common complication was lower limb ischaemia secondary to arterial cannulation. In the majority of studies this was a transient complication, but five cases of compartment syndrome and one case of lower limb amputation were reported. In studies where venovenous $\mathrm{ECCO}_{2} \mathrm{R}$ was used, clotting within the circuit is the main complication, with catheter and membrane malfunction also reported. Studies conducted before 2000 (all using venovenous $\mathrm{ECCO}_{2} \mathrm{R}$; Table 5) report higher rates of diffuse bleeding or at sites other than that where cannula insertion has occurred.

Several studies reported on transfusion requirements in those receiving $\mathrm{ECCO}_{2} \mathrm{R}$. The Xtravent trialists [19] described a significant increase in the requirement for red cell transfusion in the $\mathrm{ECCO}_{2} \mathrm{R}$ group, between randomisation and day 10, compared with the control group $(3.7 \pm 2.4$ versus $1.5 \pm 1.3$ units, $P<0.05)$. Likewise, Morris and colleagues reported a significantly higher red cell transfusion rate in those undergoing $\mathrm{ECCO}_{2} \mathrm{R}$ versus controls $(11.1 \pm 2.3$ versus $3.6 \pm 0.8 \mathrm{l} /$ ICU stay) [18].

\section{Impact on sedation/analgesia}

Two studies reported on sedative/analgesic requirements $[19,26]$. In the Xtravent study, $\mathrm{ECCO}_{2} \mathrm{R}$ patients had a lower cumulative dose of opioid and benzodiazepine than those in the control group [19]. Similarly in 
Table 4 Principal respiratory outcomes in nonrandomised studies

\begin{tabular}{|c|c|c|c|c|c|c|}
\hline Study & Time & $\begin{array}{l}\mathrm{PaCO}_{2} \text { change } \\
(\mathrm{mmHg})\end{array}$ & $\begin{array}{l}\text { Change in } \mathrm{PaO}_{2} / \mathrm{FiO}_{2} \\
(\mathrm{mmHg})\end{array}$ & $\begin{array}{l}\text { Pplat change } \\
(\mathrm{mmHg})\end{array}$ & $\mathrm{V}_{\mathrm{t}}$ reduction & pH change \\
\hline $\begin{array}{l}\text { Forster and } \\
\text { colleagues [25] }\end{array}$ & 4 hours & $\begin{array}{l}68.00 \pm 8.28 \text { to } 49.6 \pm \\
6.18\end{array}$ & $\mathrm{NR}$ & $\begin{array}{l}19.8 \pm 2.0 \text { to } 19.0 \pm \\
2.4\end{array}$ & $\begin{array}{l}8.41 \pm 0.30 \text { to } 8.34 \pm \\
1.04\end{array}$ & $\begin{array}{l}7.18 \pm 0.08 \text { to } 7.30 \pm \\
0.07\end{array}$ \\
\hline $\begin{array}{l}\text { Nierhaus and } \\
\text { colleagues [29] }\end{array}$ & Day 1 & $\begin{array}{l}80.0 \pm 23.0 \text { to } 54.0 \pm \\
19.0\end{array}$ & $\begin{array}{l}100.0 \pm 28.9 \text { to } 120.7 \\
\pm 51.2\end{array}$ & $\begin{array}{l}34.0 \pm 3.0^{\mathrm{b}} \text { to } 28.3 \pm \\
4.0\end{array}$ & $\begin{array}{l}292.5 \pm 94.0^{\mathrm{a}} \text { to } 183.0 \\
\pm 67.0\end{array}$ & $\begin{array}{l}7.18 \pm 0.22 \text { to } 7.37 \pm \\
0.09\end{array}$ \\
\hline $\begin{array}{l}\text { Weber-Carstens and } \\
\text { colleagues [26] }\end{array}$ & NR & $\begin{array}{l}120(81.9 \text { to } 152.5) \text { to } \\
60.3(52.5 \text { to } 69)\end{array}$ & $\begin{array}{l}121.5(79.3 \text { to } 178.3) \\
\text { to } 87(73 \text { to } 139.3)\end{array}$ & $\begin{array}{l}39(34.8 \text { to } 43.3) \text { to } \\
31.5(28.8 \text { to } 33.5)\end{array}$ & $\begin{array}{l}5.2(4.4 \text { to } 5.9) \text { to } 3.5 \\
(3.1 \text { to } 4.3)^{\mathrm{b}}\end{array}$ & $\begin{array}{l}7.06 \text { (6.9 to } 7.3) \text { to } \\
7.38 \text { (7.18 to } 7.48)\end{array}$ \\
\hline $\begin{array}{l}\text { Zimmermann and } \\
\text { colleagues [20] }\end{array}$ & 24 hours & $\begin{array}{l}73 \text { (61 to } 86) \text { to } 41 \\
\text { (34 to } 48)\end{array}$ & $\begin{array}{l}75(62 \text { to } 130) \text { to } 110 \\
\text { (86 to } 160)\end{array}$ & $\begin{array}{l}35 \text { ( } 31 \text { to } 38) \text { to } 30 \\
\text { (26 to } 34 \text { ) }\end{array}$ & $\begin{array}{l}6.6(5.3 \text { to } 7.2) \text { to } 4.4 \\
(3.4 \text { to } 5.4)^{b}\end{array}$ & $\begin{array}{l}7.23 \text { (7.16 to } 7.30) \text { to } \\
7.44 \text { (7.37 to } 7.45)\end{array}$ \\
\hline $\begin{array}{l}\text { Terragni and } \\
\text { colleagues [21] }\end{array}$ & $N R$ & $\begin{array}{l}47.2 \pm 8.6 \text { to } 73.6 \pm \\
11.1\end{array}$ & $N R$ & NR & $N R$ & $\begin{array}{l}7.20 \pm 0.02 \text { to } 7.38 \pm \\
0.04\end{array}$ \\
\hline $\begin{array}{l}\text { Muellenbach and } \\
\text { colleagues [27] }\end{array}$ & 12 hours & $\begin{array}{l}65.26 \text { (54 to } 72) \text { to } \\
39.8 \text { (36 to } 42)\end{array}$ & $\begin{array}{l}61.6(47.3 \text { to } 85.6) \text { to } \\
135.8(87.8 \text { to } 153)\end{array}$ & NR & $\begin{array}{l}450(400 \text { to } 542.5) \text { to } \\
200(145 \text { to } 250)^{\mathrm{a}}\end{array}$ & $\begin{array}{l}7.25 \text { (7.22 to } 7.29) \text { to } \\
7.4(7.37 \text { to } 7.42)\end{array}$ \\
\hline $\begin{array}{l}\text { Bein and colleagues } \\
{[28]}\end{array}$ & 24 hours & $\begin{array}{l}60 \text { ( } 48 \text { to } 80) \text { to } 34 \\
\text { (30 to } 39)\end{array}$ & $\begin{array}{l}58 \text { ( } 47 \text { to } 78) \text { to } 107 \\
\text { (74 to } 142 \text { ) }\end{array}$ & NR & $\begin{array}{l}430(360 \text { to } 540) \text { to } \\
380(320 \text { to } 470)^{\mathrm{a}}\end{array}$ & $\begin{array}{l}7.27 \text { (7.18 to } 7.36) \text { to } \\
7.45(7.41 \text { to } 7.50)\end{array}$ \\
\hline $\begin{array}{l}\text { Liebold and } \\
\text { colleagues [30] }\end{array}$ & 24 hours & $59 \pm 17$ to $32 \pm 8$ & 50 to 110 & NR & NR & NR \\
\hline $\begin{array}{l}\text { Guinard and } \\
\text { colleagues [22] }\end{array}$ & NR & NR & NR & NR & $N R$ & $N R$ \\
\hline $\begin{array}{l}\text { Brunet and } \\
\text { colleagues [23] }\end{array}$ & NR & $66 \pm 25$ to $43 \pm 6$ & $79 \pm 21$ to $207 \pm 108$ & $48 \pm 10$ to $37 \pm 5$ & $\begin{array}{l}622 \pm 131 \text { to } 270 \pm \\
60^{a}\end{array}$ & NR \\
\hline $\begin{array}{l}\text { Bindslev and } \\
\text { colleagues [31] }\end{array}$ & NR & NR & NR & NR & NR & NR \\
\hline $\begin{array}{l}\text { Gattinoni and } \\
\text { colleagues [24] }\end{array}$ & NR & NR & NR & NR & NR & NR \\
\hline
\end{tabular}

Data presented as mean \pm standard deviation or median (range). $\mathrm{NR}$, not recorded; $\mathrm{FiO}_{2}$, fraction of inspired oxygen; PaCO ${ }_{2}$, partial pressure of arterial carbon dioxide; $\mathrm{PaO}_{2}$, partial pressure of arterial oxygen; Pinsp, inspiratory pressure; Pplat, plateau pressure; $\mathrm{V}_{\mathrm{t}}$, tidal volume. ${ }^{\mathrm{a} U n i t s}$ are millilitres. ${ }^{\mathrm{b}}$ Units

are millilitres/kilogram.

Weber-Carstens and colleagues' 2009 study, patients required lower doses of opioid (fentanyl: 8.9 to $4.4 \mathrm{mg} / \mathrm{kg} /$ hour) and benzodiazepine (midazolam: 0.28 to $0.19 \mathrm{mg} /$ $\mathrm{kg} /$ hour) after 4 days of $\mathrm{ECCO}_{2} \mathrm{R}$ treatment [26].

\section{Biomarkers}

The role of biomarkers in predicting severity or mortality from ARDS is not straightforward. Attempts to identify a biomarker for ARDS have not thus far been successful [36,37].

Only two of the included studies $[19,21]$ evaluated the use of $\mathrm{ECCO}_{2} \mathrm{R}$ and biomarkers, and neither dataset was complete. The Xtravent study measured serum levels of proinflammatory cytokines tumour necrosis factor alpha, IL- 6 and IL-8 in 20 patients who underwent $\mathrm{ECCO}_{2} \mathrm{R}$ and in 15 controls [19]. IL-6 levels decreased in the $\mathrm{ECCO}_{2} \mathrm{R}$ group in the first 24 hours. Tumour necrosis factor alpha and IL- 8 were unchanged. The study by Terragni and colleagues included assessment of IL-6, IL-8, IL-1b, and IL-1ra in 10 patients with higher plateau pressure of 28 to 30, and in 15 of 22 patients with lower plateau pressures [21]. In patients with higher plateau pressures, the use of $\mathrm{ECCO}_{2} \mathrm{R}$ to facilitate a reduction in pressure was associated with a significant reduction in pulmonary inflammatory mediators. This association suggests that inflammatory cytokines may be a useful surrogate outcome in phase 2 studies, although it is unclear whether a change in inflammatory cytokines translates into improved clinical outcomes.

\section{Discussion}

This comprehensive systematic review examined two RCTs and 12 observational studies that treated 495 patients with acute respiratory failure with $\mathrm{ECCO}_{2} \mathrm{R}$ and found a paucity of high-quality clinical trials evaluating its use. Differing modalities of $\mathrm{ECCO}_{2} \mathrm{R}$ were compared, with arteriovenous $\mathrm{ECCO}_{2} \mathrm{R}$ being used in seven studies and venovenous $\mathrm{ECCO}_{2} \mathrm{R}$ in seven studies.

Our findings indicate that robust data supporting the use of these devices are lacking. Both RCTs were terminated early for futility and therefore it was not possible to determine an effect on mortality. Although no mortality benefit was shown, a post hoc analysis of the most recent RCT [19] indicated that a subset of patients with moderately severe ARDS demonstrated a trend towards more VFDs at 60 days and a shorter ICU length of stay. This post hoc analysis aids in determining optimal indications for use and design of future trials.

Patients with more severe respiratory failure $\left(\mathrm{PaO}_{2} / \mathrm{FiO}_{2}\right.$ $<150$ ) may be an appropriate population of patients to 
Table 5 Complications of extracorporeal carbon dioxide removal

\begin{tabular}{|c|c|c|c|c|}
\hline Study & Year & Modality & $\begin{array}{l}\text { Complication } \\
\text { rate }(\%)\end{array}$ & Description \\
\hline $\begin{array}{l}\text { Forster and } \\
\text { colleagues [25] }\end{array}$ & 2013 & $\begin{array}{l}\text { W (with } \\
\text { CRRT) }\end{array}$ & Nil & \\
\hline $\begin{array}{l}\text { Bein and colleagues } \\
\text { [19] }\end{array}$ & 2013 & AV & 7.5 & $1 \times$ lower limb ischaemia, $2 \times$ aneurysm \\
\hline $\begin{array}{l}\text { Nierhaus and } \\
\text { colleagues [29] }\end{array}$ & 2011 & AV & 21.4 & $2 \times$ catheter displacement, $1 \times$ bleeding at insertion site \\
\hline $\begin{array}{l}\text { Weber-Carstens and } \\
\text { colleagues [26] }\end{array}$ & 2009 & AV & 6.3 & $1 \times$ transient occlusion of femoral artery during cannulation \\
\hline $\begin{array}{l}\text { Zimmermann and } \\
\text { colleagues [20] }\end{array}$ & 2009 & AV & 11.8 & $\begin{array}{l}3 \times \text { lower limb ischaemia, } 1 \times \text { cannula thrombosis, } 1 \times \text { bleeding during cannulation, } 1 \times \\
\text { compartment syndrome }\end{array}$ \\
\hline $\begin{array}{l}\text { Terragni and } \\
\text { colleagues [21] }\end{array}$ & 2009 & W & 25 & $\begin{array}{l}1 \times \text { pump malfunction, } 3 \times \text { membrane/haemofilter clotting, } 1 \times \text { catheter displacement, } 3 \times \\
\text { cannula problems }\end{array}$ \\
\hline $\begin{array}{l}\text { Muellenbach and } \\
\text { colleagues [27] }\end{array}$ & 2008 & AV & 23 & $\begin{array}{l}2 \times \text { lower limb ischaemia, } 1 \times \text { femoral artery pseudoaneurysm, } 1 \times \text { lower limb amputation, } \\
1 \times \text { catheter displacement }\end{array}$ \\
\hline $\begin{array}{l}\text { Bein and colleagues } \\
\text { [28] }\end{array}$ & 2006 & AV & 24.4 & $\begin{array}{l}9 \times \text { lower limb ischaemia, } 4 \times \text { cannula thrombosis, } 4 \times \text { compartment syndrome, } 2 \times \\
\text { aneurysm, } 1 \times \text { haemolysis, } 1 \times \text { intracerebral haemorrhage, } 1 \times \text { diffuse bleeding with shock } \\
\text { on cannulation }\end{array}$ \\
\hline $\begin{array}{l}\text { Liebold and } \\
\text { colleagues [30] }\end{array}$ & 2002 & AV & 21 & $\begin{array}{l}7 \times \text { cannula thrombosis, } 1 \times \text { membrane clotting, } 3 \times \text { lower limb ischaemia, } 5 \times \text { membrane } \\
\text { plasma leakage }\end{array}$ \\
\hline $\begin{array}{l}\text { Guinard and } \\
\text { colleagues [22] }\end{array}$ & 1997 & W & NR & NR \\
\hline $\begin{array}{l}\text { Morris and } \\
\text { colleagues [18] }\end{array}$ & 1994 & W & NR & $21 \times$ non-CNS haemorrhage (7 requiring discontinuation of $\mathrm{ECCO}_{2} \mathrm{R}$ ), $4 \times$ circuit clotting \\
\hline $\begin{array}{l}\text { Brunet and } \\
\text { colleagues [23] }\end{array}$ & 1994 & W & 18.2 & $1 \times$ alveolar haemorrhage, $1 \times$ diffuse bleeding \\
\hline $\begin{array}{l}\text { Bindslev and } \\
\text { colleagues [31] }\end{array}$ & 1991 & W & NR & $1 \times$ allergic reaction \\
\hline $\begin{array}{l}\text { Gattinoni and } \\
\text { colleagues [24] }\end{array}$ & 1986 & W & NR & $3 \times$ intra-pulmonary bleeding \\
\hline
\end{tabular}

$\mathrm{AV}$, arteriovenous; CNS, central nervous system; CRRT, continuous renal replacement therapy; $\mathrm{ECCO}_{2} \mathrm{R}$, extracorporeal carbon dioxide removal; $\mathrm{NR}$, not reported; $\mathrm{V}$, venovenous.

recruit for subsequent RCTs because $\mathrm{ECCO}_{2} \mathrm{R}$ may have a better risk-benefit profile in more severely ill patients, who are at a high risk of dying. Data from the UK Intensive Care National Audit and Research Centre (ICNARC), which collects information from $95 \%$ of ICUs in the United Kingdom, found that more than 18,500 of approximately 130,000 mechanically ventilated patients in 2012 had $\mathrm{PaO}_{2} /$ $\mathrm{FiO}_{2}<150$. This cohort had a $40 \%$ ICU mortality and almost $50 \%$ hospital mortality. These results provide an estimation of the population who might benefit from $\mathrm{ECCO}_{2} \mathrm{R}$ if proven to be effective in this cohort.

Complication rates varied across the papers but the pattern suggested that increasing familiarity led to lower rates of complications. Comparing the Zimmermann and colleagues [20] and Bein and colleagues [28] nonrandomised papers from the same single centre in Regensburg, Germany, complication rates decreased from $24.4 \%$ in the earlier period to $11.9 \%$ in the prospective study. This highlights the importance of training in the introduction of the technology, and perhaps limiting its use to sites with expertise. Earlier studies demonstrated a high rate of haemorrhagic complications due to the need for systemic anticoagulation, particularly in older venovenous circuits. Newer circuits have heparinbonded surfaces, which obviates this need. With this novel technology, there has been a decrease in bleeding rates, as demonstrated by Knoch and colleagues in 1992 [38], although bleeding remains a risk.

The increasing red cell requirement, reported not only in the Morris and colleagues study [18] but also in the more recent Xtravent study [19], represents a meaningful concern regarding $\mathrm{ECCO}_{2} \mathrm{R}$ use. There is evidence that red cell transfusion is associated with increased development of ARDS [39], and increasing mortality for critically ill patients [40]. Future study of these devices should assess need for red cell transfusion carefully.

Both the Xtravent study [19] and the Weber-Carstens and colleagues study [26] showed decreased need for sedation and analgesia in patients with application of $\mathrm{ECCO}_{2} \mathrm{R}$; lower sedation levels have previously been associated with shorter ventilation time, shorter ICU and hospital stays, and lower mortality rates $[41,42]$. 
Data are lacking on the cost-effectiveness of this therapy. Morris and colleagues' study estimated an increase in hospital costs of approximately $20 \%$ per day for $\mathrm{ECCO}_{2} \mathrm{R}$ versus control patients [18]; this was probably an underestimate because increased technical staffing costs were not included. Gattinoni and colleagues' study demonstrated that $\mathrm{ECCO}_{2} \mathrm{R}$ in the 1980 s was associated with a doubling of cost per day of ICU therapy [24]. Bindslev and colleagues' 1991 study estimated that the daily cost of a patient on extracorporeal assistance is approximately three times greater than that for a standard ICU bed [31]. None of the other studies discussed here included a formal economic analysis. The potential benefits of this therapy are not yet proven, and certainly concerns still exist about its efficacy, side effects and costs. Further clinical trials should also include a health economic analysis to determine the cost-effectiveness of $\mathrm{ECCO}_{2} \mathrm{R}$.

Carbon dioxide removal is quantitatively possible using strategies of $\mathrm{ECCO}_{2} \mathrm{R}$, as reported in almost all of the studies. The Xtravent RCT and recent nonrandomised studies demonstrate that ventilation with very low tidal volume ventilation was feasible and safe with $\mathrm{ECCO}_{2} \mathrm{R}$. While in some models respiratory acidosis has been shown to decrease pulmonary inflammatory cytokines [43], this may be attributable to an improvement in shear stress, and the role of hypercapnic acidosis in this setting is incompletely understood. Robust studies have demonstrated reductions in inflammatory cytokines $[21,44]$ and improved outcomes [3] as a consequence of lower tidal volume ventilation. In addition, in the clinical situation, where respiratory and metabolic acidosis may co-exist, buffering or control of acidosis may be required in patients intolerant of acidaemia; for example, traumatic brain injury. This is an important point in considering the design of future clinical trials of $\mathrm{ECCO}_{2} \mathrm{R}$ where the primary objective should be limitation of injurious ventilation rather than reversal of respiratory acidosis.

The optimal timing for use of $\mathrm{ECCO}_{2} \mathrm{R}$ remains unclear, although retrospective analysis has shown that a shorter period of mechanical ventilation (3 versus 5 days) before application of the device is associated with an improved mortality rate [20]. One group used $\mathrm{ECCO}_{2} \mathrm{R}$ as a rescue strategy following prolonged ventilation $(9.9 \pm$ 6.2 days) [22] and mortality rates were particularly high in this group (75\%).

The strength of this review is that we adhered closely to our protocol, which outlined our procedures for minimising bias in the review: these included independent screening for study inclusion, data extraction and assessment of quality by two authors. With the assistance of an experienced librarian, we conducted a thorough search strategy and believe we have identified all relevant studies.
Although the recent RCT has added useful information on current $\mathrm{ECCO}_{2} \mathrm{R}$ use as a well-designed multicentre study with a low risk of bias [19], there is still a paucity of high-quality evidence in this area, and a need for adequately powered clinical studies. This is an area where rapid technological advances have been made in the last 10 years, representing major changes in the component sophistication and efficacy of $\mathrm{ECCO}_{2} \mathrm{R}$. This confounds attempts to compare devices when a systematic review is attempted. Differences in vascular access, pumped versus nonpumped systems, cardiovascular status of the patient, need for full anti-coagulation, and more efficient modern extraction abilities all complicate analysis.

Our work has some limitations, including those common to all systematic reviews. We are reliant on the available evidence, and over one-half of included studies were case series, which are graded as 3 (that is, lowquality evidence) [45] (Table 2). Only two RCTs on the use of $\mathrm{ECCO}_{2} \mathrm{R}$ (graded as level 1+) were conducted, both of which stopped early and had a time interval of 19 years between them and associated differences in practice. As such, they offer limited information to inform practice. A formal meta-analysis of the data was not possible because there were only two RCTs with significant heterogeneity within those studies.

The UK National Institute of Clinical Evidence guidelines on $\mathrm{ECCO}_{2} \mathrm{R}$ state that 'evidence on its efficacy is limited in quantity and quality' [46]. The 2010 Canadian Health Technology Assessment found that arteriovenous $\mathrm{ECCO}_{2} \mathrm{R}$ is efficacious regarding carbon dioxide removal and can therefore facilitate lung protective ventilator strategies, but like our review it found no evidence of improved long-term survival [34].

We found two ongoing studies. First is a clinical trial that is currently recruiting in Turin, with the aim of comparing ultra-low tidal volume ventilation $(4 \mathrm{ml} / \mathrm{kg}$ predicted body weight) with low tidal volume ventilation ( $6 \mathrm{ml} / \mathrm{kg}$ predicted body weight), using $\mathrm{ECCO}_{2} \mathrm{R}$ to facilitate this [47]. This is a randomised nonblinded study, with the aim to recruit 230 patients over 12 to 18 months. The other ongoing study is recruiting to assess $\mathrm{ECCO}_{2} \mathrm{R}$ combined with early renal replacement therapy [48]. The Xtravent study was conducted in 10 centres over 40 months and yet only 79 patients were enrolled [19], underlining the difficulties of enrolment in this patient population.

Our review indicates a state of clinical equipoise on the benefits of $\mathrm{ECCO}_{2} \mathrm{R}$ in acute respiratory failure. There is a trend towards improved outcomes as indicated by more VFDs with the application of modern $\mathrm{ECCO}_{2} \mathrm{R}$ in patients with more severe disease; however, definitive data are as yet lacking. Questions regarding the optimal device, timing and patient selection will be best answered by further rigorous and well-designed RCTs. 


\section{Conclusions}

$\mathrm{ECCO}_{2} \mathrm{R}$ is an area of rapidly evolving technology and increasing rates of utilisation. As physicians, nurses and technical staff gain familiarity with this technology, its use is likely to increase. As a treatment modality for respiratory failure and $\mathrm{ARDS}, \mathrm{ECCO}_{2} \mathrm{R}$ is efficacious as a treatment for hypercapnia, facilitating ultra-low tidal volume ventilation. There is some indication that patients with moderately severe disease in whom $\mathrm{ECCO}_{2} \mathrm{R}$ is employed at an early stage may benefit. However, evidence for a reduction in mortality and other important clinical outcomes is still lacking.

\section{Additional files}

Additional file 1: The full MEDLINE search strategy.

Additional file 2: The pre-piloted data extraction form.

Additional file 3: A table presenting excluded articles [49-54].

\section{Abbreviations}

ARDS: Acute respiratory distress syndrome; $\mathrm{ECCO}_{2} \mathrm{R}$ : Extracorporeal carbon dioxide removal; $\mathrm{FiO}_{2}$ : Fraction of inspired oxygen; ICNARC: Intensive Care National Audit and Research Centre; IL: Interleukin; LILACS: Literatura Latino Americana em Ciências da Saúde; $\mathrm{PaO}_{2}$ : Partial pressure of arterial oxygen; RCT: Randomised controlled trial; VFD: Ventilator-free day.

\section{Competing interests}

The authors declare that they have no competing interests.

\section{Authors' contributions}

JJM, DFM, MF and BB conceived the review. All authors made a substantial contribution to the protocol development. MF and JM extracted the data and drafted the manuscript. All authors were involved in analysis and interpretation of data, critically revised the manuscript and approved the final manuscript.

\section{Acknowledgements}

The authors wish to thank the Intensive Care Foundation for their help and support; and also Richard Fallis, Medical Librarian in the Medical Library of the Royal Victoria Hospital Belfast, for his help in designing and implementing the search strategy. The data quoted from ICNARC derive from the Case Mix Programme Database. The Case Mix Programme is the national, comparative audit of patient outcomes from adult critical care coordinated by ICNARC. These analyses are based on data for 133,266 admissions to 203 adult, general critical care units based in National Health Service hospitals geographically spread across England, Wales and Northern Ireland. For more information on the representativeness and quality of these data, please contact ICNARC.

\section{Published: 15 May 2014}

\section{References}

1. Villar J, Blanco J, Anon JM, Santos-Bouza A, Blanch L, Ambros A, Gandia F, Carriedo D, Mosteiro F, Basaldua S, Fernandez RL, Kacmarek RM, ALIEN Network: The ALIEN study: incidence and outcome of acute respiratory distress syndrome in the era of lung protective ventilation. Intensive Care Med 2011, 37:1932-1941.

2. Tremblay LN, Slutsky AS: Ventilator-induced lung injury: from the bench to the bedside. Intensive Care Med 2006, 32:24-33.

3. ARDS Network: Ventilation with lower tidal volumes as compared with traditional tidal volumes for acute lung injury and the acute respiratory distress syndrome. N Engl J Med 2000, 342:1301-1308.

4. Rubenfeld GD, Cooper C, Carter G, Thompson BT, Hudson LD: Barriers to providing lung-protective ventilation to patients with acute lung injury. Crit Care Med 2004, 32:1289-1293.
5. Cove ME, Maclaren G, Federspiel WJ, Kellum JA: Bench to bedside review: Extracorporeal carbon dioxide removal, past present and future. Crit Care 2012, 16:232.

6. Gattinoni L, Kolobow T, Tomlinson T, lapichino G, Samaja M, White D, Pierce J: Low-frequency positive pressure ventilation with extracorporeal carbon dioxide removal (LFPPV-ECCO 2 R): an experimental study. Anesth Analg 1978, 57:470-477.

7. Gattinoni L, Kolobow T, Tomlinson T, White D, Pierce J: Control of intermittent positive pressure breathing (IPPB) by extracorporeal removal of carbon dioxide. Br J Anaesth 1978, 50:753-758.

8. Brunet F, Belghith M, Mira JP, Lanore JJ, Vaxelaire JF, Dall'ava Santucci J, Dhainaut JF: Extracorporeal carbon dioxide removal and low-frequency positive-pressure ventilation. Improvement in arterial oxygenation with reduction of risk of pulmonary barotrauma in patients with adult respiratory distress syndrome. Chest 1993, 104:889-898.

9. Moerer O, Quintel M: Protective and ultra-protective ventilation: using pumpless interventional lung assist (iLA). Minerva Anestesiol 2011, 77:537-544.

10. Fitzgerald M, Millar J, Blackwood B, Davies A, Brett SJ, McAuley DF, McNamee JJ: Effectiveness of extra-corporeal $\mathrm{CO} 2$ removal for patients with respiratory failure secondary to adult respiratory distress syndrome. PROSPERO International Prospective Register of Systematic Reviews. [http://www.crd.york.ac.uk/NIHR_PROSPERO/].

11. Liberati A, Altman DG, Tetzlaff J, Mulrow C, Gøtzsche PC, loannidis JP, Clarke M, Devereaux PJ, Kleijnen J, Moher D: The PRISMA statement for reporting systematic reviews and meta-analyses of studies that evaluate healthcare interventions: explanation and elaboration. BMJ 2009, 339:b2700.

12. ClinicalTrials. [http://www.clinicaltrials.gov].

13. Current Controlled Trials. [http://www.controlled-trials.com].

14. NIHR Portal. [http://www.portal.nihr.ac.uk].

15. UK Critical Appraisal Skills Programme. [http://www.casp-uk.net].

16. Chan K, Bhandari M: Three-minute critical appraisal of a case series. Indian J Orthop 2011, 45:103-104.

17. Cochrane Handbook for Systematic Reviews of Interventions Version 5.1.0. [www.cochrane-handbook.org].

18. Morris AH, Wallace CJ, Menlove RL, Clemmer TP, Orme JF Jr, Weaver LK, Dean NC, Thomas F, East TD, Pace NL, Suchyta MR, Beck E, Bombino M, Sittig DF, Böhm S, Hoffmann B, Becks H, Butler S, Pearl J, Rasmusson B: Randomized clinical trial of pressure-controlled inverse ratio ventilation and extracorporeal $\mathrm{CO}_{2}$ removal for adult respiratory distress syndrome. Am J Respir Crit Care Med 1994, 149(2 Pt 1):295-305.

19. Bein T, Weber-Carstens $S$, Goldmann A, Müller T, Staudinger T, Brederlau J, Muellenbach R, Dembinski R, Graf BM, Wewalka M, Philipp A, Wernecke KD, Lubnow M, Slutsky AS: Lower tidal volume strategy $(\approx 3 \mathrm{ml} / \mathrm{kg})$ combined with extracorporeal $\mathrm{CO}_{2}$ removal versus 'conventional' protective ventilation $(6 \mathrm{ml} / \mathrm{kg})$ in severe ARDS: the prospective randomized Xtravent-study. Intensive Care Med 2013, 39:847-856.

20. Zimmermann M, Bein T, Arlt M, Philipp A, Rupprecht L, Mueller T, Lubnow M, Graf BM, Schlitt HJ: Pumpless extracorporeal interventional lung assist in patients with acute respiratory distress syndrome: a prospective pilot study. Crit Care 2009, 13:R10.

21. Terragni PP, Del Sorbo L, Mascia L, Urbino R, Martin EL, Birocco A, Faggiano C, Quintel M, Gattinoni L, Ranieri VM: Tidal volume lower than $6 \mathrm{ml} / \mathrm{kg}$ enhances lung protection: role of extracorporeal carbon dioxide removal. Anesthesiology 2009, 111:826-835.

22. Guinard N, Beloucif S, Gatecel C, Mateo J, Payen D: Interest of a therapeutic optimization strategy in severe ARDS. Chest 1997, 111:1000-1007.

23. Brunet F, Mira JP, Belghith M, Monchi M, Renaud B, Fierobe L, Hamy I, Dhainaut JF, Dall'ava-Santucci J: Extracorporeal carbon dioxide removal technique improves oxygenation without causing overinflation. Am J Respir Crit Care Med 1994, 149:1557-1562.

24. Gattinoni L, Pesenti A, Mascheroni D, Marcolin R, Fumagalli R, Rossi F, lapichino G, Romagnoli G, Uziel L, Agostoni A, Kolobow T, Damia G: Low-frequency positive-pressure ventilation with extracorporeal $\mathrm{CO}_{2}$ removal in severe acute respiratory failure. JAMA 1986, 256:881-886.

25. Forster C, Schriewer J, John S, Eckardt KU, Willam C: Low-flow $\mathrm{CO}_{2}$ removal integrated into a renal-replacement circuit can reduce acidosis and decrease vasopressor requirements. Crit Care 2013,

17:R154.

26. Weber-Carstens S, Bercker S, Hommel M, Deja M, MacGuill M, Dreykluft C, Kaisers U: Hypercapnia in late-phase ALI/ARDS: providing spontaneous 
breathing using pumpless extracorporeal lung assist. Intensive Care Med 2009, 35:1100-1105.

27. Muellenbach RM, Kredel M, Wunder C, Küstermann J, Wurmb T, Schwemmer U, Schuster F, Anetseder M, Roewer N, Brederlau J: Arteriovenous extracorporeal lung assist as integral part of a multimodal treatment concept: a retrospective analysis of 22 patients with ARDS refractory to standard care. Eur J Anaesthesiol 2008, 25:897-904.

28. Bein T, Weber F, Philipp A, Prasser C, Pfeifer M, Schmid FX, Butz B, Birnbaum D, Taeger K, Schlitt HJ: A new pumpless extracorporeal interventional lung assist in critical hypoxemia/hypercapnia. Crit Care Med 2006, 34:1372-1377.

29. Nierhaus A, Frings D, Braune S, Baumann HJ, Schneider C, Wittenburg B, Kluge $S$ : Interventional lung assist enables lung protective mechanical ventilation in acute respiratory distress syndrome. Minerva Anestesiol 2011 77:797-801

30. Liebold A, Philipp A, Kaiser M, Merk J, Schmid FX, Birnbaum DE: Pumpless extracorporeal lung assist using an arterio-venous shunt. Applications and limitations. Minerva Anestesiol 2002, 68:387-391.

31. Bindslev L, Böhm C, Jolin A, Hambraeus Jonzon K, Olsson P, Ryniak S: Extracorporeal carbon dioxide removal performed with surfaceheparinized equipment in patients with ARDS. Acta Anaesthesiol Scand Suppl 1991, 95:125-130.

32. Mattei $\mathrm{N}$, Mocavero $\mathrm{P}$, Corcione $\mathrm{A}$ : Extracorporeal $\mathrm{CO}_{2}$ removal in ICU [abstract]. Eur J Anaesthesiol 2011, 28(Suppl):170.

33. Atalan HK, Dumantepe M, Denizalti TB, Tarhan IA, Ozler A: Combined use of pumpless extracorporeal lung assist system and continuous renal replacement therapy with citrate anticoagulation in polytrauma patients [abstract]. Crit Care 2013, 17(Suppl):S23.

34. Health Quality Ontario: Extracorporeal lung support technologies - bridge to recovery and bridge to lung transplantation in adult patients: an evidence-based analysis. Ont Health Technol Assess Ser 2010, 10:1-47.

35. Phua J, Badia JR, Adhikari NK, Friedrich JO, Fowler RA, Singh JM, Scales DC, Stather DR, Li A, Jones A, Gattas DJ, Hallett D, Tomlinson G, Stewart TE, Ferguson ND: Has mortality from acute respiratory distress syndrome decreased over time? A systematic review. Am J Respir Crit Care Med 2009, 179:220-227.

36. Terpstra ML, Aman J, van Nieuw Amerongen GP, Groeneveld AB: Plasma biomarkers for acute respiratory distress syndrome: a systematic review and meta-analysis. Crit Care Med 2014, 42:691-700.

37. Tzouvelekis A, Pneumatikos I, Bouros D: Serum biomarkers in acute respiratory distress syndrome an ailing prognosticator. Respir Res 2005, 6:62.

38. Knoch M, Köllen B, Dietrich G, Müller E, Mottaghy K, Lennartz H: Progress in veno-venous long-term bypass techniques for the treatment of ARDS. Controlled clinical trial with the heparin-coated bypass circuit. Int J Artif Organs 1992, 15:103-108

39. Gong MN, Thompson BT, Williams P, Pothier L, Boyce PD, Christiani D: Clinical predictors of and mortality in acute respiratory distress syndrome: potential role of red cell transfusion. Crit Care Med 2005, 33:1191-1198,

40. Hébert PC, Wells G, Blajchman MA, Marshall J, Martin C, Pagliarello G, Tweeddale M, Schweitzer I, Yetisir E, Transfusion Requirements in Critical Care Investigators, Canadian Critical Care Trials Group: A multicenter, randomized, controlled clinical trial of transfusion requirements in critical care. N Engl J Med 1999, 340:409-417.

41. Strøm T, Martinussen T, Toft P: A protocol of no sedation for critically ill patients. Lancet 2010, 375:475-480.

42. Shehabi Y, Bellomo R, Reade MC, Bailey M, Bass F, Howe B, McArthur C, Seppelt IM, Webb S, Weisbrodt L, Sedation Practice in Intensive Care Evaluation (SPICE) Study Investigators; ANZICS Clinical Trials Group: Early intensive care sedation predicts long-term mortality in ventilated critically ill patients. Am J Respir Crit Care Med 2012, 186:724-731.

43. Laffey JG, Honan D, Hopkins N, Hyvelin JM, Boylan JF, McLoughlin P: Hypercapnic acidosis attenuates endotoxin-induced acute lung injury. Am J Respir Crit Care Med 2004, 169:46-56.

44. Ranieri VM, Suter PM, Tortorella C, De Tullio R, Dayer JM, Brienza A, Bruno F, Slutsky AS: Effect of mechanical ventilation on inflammatory mediators in patients with acute respiratory distress syndrome: a randomized controlled trial. JAMA 1999, 282:54-61.

45. Harbour R, Miller J, Scottish Intercollegiate Guidelines Network Grading Review Group: A new system for grading recommendations in evidence based guidelines. BMJ 2001, 323:334-336.
46. Extracorporeal Membrane Carbon Dioxide Removal. NICE interventional Procedure Guidance 428. [http://guidance.nice.org.uk/ipg428].

47. Flow-flow ECCO2-R and $4 \mathrm{ml} / \mathrm{kg}$ Tidal Volume vs. $6 \mathrm{ml} / \mathrm{kg}$ Tidal Volume to Enhance Protection From VILI in Acute Lung Injury. [http://clinicaltrials. gov/ct2/show/NCT01522599?term=NCT01522599\&rank=1].

48. Pulmonary and Renal Support During Acute Respiratory Distress Syndrome. [http://clinicaltrials.gov/ct2/results?term=NCT01239966\&Search= Search].

\section{$10.1186 / \operatorname{cc} 13875$}

Cite this article as: Fitzgerald et al.: Extracorporeal carbon dioxide removal for patients with acute respiratory failure secondary to the acute respiratory distress syndrome: a systematic review. Critical Care 2014, 18:222 